\title{
C, N, P, S content of the Chlorophyta Chaetomorpha linum (Müller) Kützing in a vast high density mat of a Mediterranean non-tidal lagoon
}

\author{
Mauro Lenzi ${ }^{1, *}$, Marco Leporatti-Persiano ${ }^{2}$ and Paola Gennaro ${ }^{3}$ \\ ${ }^{1}$ Lagoon Ecology and Aquaculture Laboratory (LEALab - WWF Oases), Strada Provinciale Giannella 154, 58015 Orbetello, Italy \\ 2 Orbetello Pesca Lagunare, Via Leopardi 9, 58015 Orbetello, Italy \\ ${ }^{3}$ ISPRA, Italian Institute for Environmental Protection and Research, Leghorn, Italy
}

Received: 1 July 2020 / Accepted: 17 August 2020

\begin{abstract}
In a Chaetomorpha linum high density mat extending over 300 hectares, between 2017 and 2019 samples were collected for C, N, P, S tissue content determination, biomass (b) was estimated, sediment samples collected for labile organic matter (LOM) determination, and water chemical-physical variables measured. The latter showed extreme conditions with a wide range of values and with zero oxygen for long periods. $\mathrm{N}_{-} \mathrm{NO}_{3}$ :SRP atomic ratio showed extreme P-limitation. Tissue macronutrients showed very variable values, highlighting a strong P-limitation and relatively high level of $\mathrm{S}$. With exception of nitrogen, no significant differences were detected for each macronutrient between the months and between the stations, neither was any correlation found between macronutrients and LOM and b data-set. The growth and survival of the mat occurred despite the scarcity of $\mathrm{P}$, which probably reached with very low frequency the surface layer of the mat, the one capable of performing photosynthesis, where it was quickly re-assimilated and utilised.
\end{abstract}

Keywords: Chaetomorpha linum / nutrient / carbon / nitrogen / phosphorus / sulphur / macroalgal mat / lagoon / eutrophication

\begin{abstract}
Résumé - Teneur en C, N, P, S de la chlorophyte Chaetomorpha linum (Müller) Kützing dans un vaste mat de haute densité d'une lagune méditerranéenne sans marée. Dans un tapis à haute densité de Chaetomorpha linum s'étendant sur 300 hectares, entre 2017 et 2019, des échantillons ont été prélevés pour la détermination de la teneur en $\mathrm{C}, \mathrm{N}, \mathrm{P}, \mathrm{S}$ des tissus, la biomasse (b) a été estimée, des échantillons de sédiments ont été prélevés pour la détermination de la matière organique labile (LOM), et les variables physico-chimiques de l'eau ont été mesurées. Ces dernières ont montré des conditions extrêmes avec une large gamme de valeurs et avec un taux d'oxygène nul pendant de longues périodes. Le rapport atomique N-NO3:SRP a montré une limitation extrême du P. Les macronutriments tissulaires ont montré des valeurs très variables, mettant en évidence une forte limitation de $\mathrm{P}$ et un niveau relativement élevé de $\mathrm{S}$. À l'exception de l'azote, aucune différence significative n'a été détectée pour chaque macronutriment entre les mois et entre les stations, et aucune corrélation n'a été trouvée entre les macronutriments et la LOM et l'ensemble de données de biomasse. La croissance et la survie du tapis se sont produites malgré la rareté du $\mathrm{P}$, qui a probablement atteint avec une très faible fréquence la couche superficielle du tapis, celle capable d'effectuer la photosynthèse, où il a été rapidement réassimilé et utilisé.
\end{abstract}

Mots-clés : Chaetomorpha linum / nutriment / carbone / azote / phosphore / soufre / tapis de macroalgues / lagune / eutrophisation

\section{Introduction}

In the past forty years, nutrient supply resulted in the excessive growth of opportunistic macroalgae in many coastal

\footnotetext{
*Corresponding author: lealab1@gmail.com
}

ecosystems of the world (Morand and Briand, 1996; Raffaelli et al., 1998; Smetacek and Zingone, 2013), which can uptake, assimilate and store nitrogen $(\mathrm{N})$ and phosphorus $(\mathrm{P})$ in large amounts. Bottom-floating macroalgal masses often accumulate along the coasts, bays and estuaries and in lagoon coasts, representing a significant biomass, and can produce high 
density mats, causing severe ecological and economic problems (Bombelli and Lenzi, 1996; Hauxwell and Valiela, 2004; Liu et al., 2009).

Many coastal lagoons have been affected by these phenomena, due to the strong human impact and their structural and morphological characteristics (Sfriso et al., 1987; Viaroli et al., 1996; Lenzi et al., 2011; Duck and Figueiredo da Silva, 2012). Macroalgal decay decreases water quality and enriches the sediment in labile organic matter, which results in widespread anoxic conditions and stimulates sulfate-reducing bacterial activity (Holmer et al., 2004) that can lead to increasingly recurrent dystrophic crises (Amanieu et al., 1975; Hargrave et al., 2008; Lenzi et al., 2011; Lenzi, 2019).

Non-tidal lagoon environments suffer even more from these phenomena, due to the scarce water exchange, shallow water, and, very often, morphology. For all these factors they have a structural tendency toward eutrophication, and are therefore particularly subject to opportunistic and galenophilic development of algal masses. Dense algal mats, sometimes well above $50 \mathrm{~cm}$ thick, also worsen the already scarce hydrodynamics, since they create areas of stagnation and modify the quality of the water significantly (Hargrave et al., 2008; Lenzi et al., 2013a; Sorce et al., 2017). Inside a macroalgal mat, Lenzi et al. (2013a) observed stratification in the water quality, and a different nutrient uptake between the under-layer and the over-layer of the mat. Krause-Jensen et al. (1996) observed a sharp gradient of light penetration towards the inside of the mat, extinguishing itself a few centimeters below the mat surface.

The success of opportunistic macroalgae, also in high density mat, is attributed to their physiological responses to abiotic factors (Cohen and Fong, 2004; Sorce et al., 2017). Since these dense mats continue to survive and grow for a long time, it remains to be understood how the over-layer, the one that can use light for photosynthesis, can thrive in conditions sometimes very limited for some nutrients.

In this study, we investigated the changes in the macronutrients $\mathrm{C}, \mathrm{N}, \mathrm{P}, \mathrm{S}$ content in a high density mat of the Chlorophyta Chaetomorpha linum, which has persisted in a lagoon over an area of 300 hectares, for over 12 years to date. We sought to establish (1) if there are evident changes in relation to seasons and mat densities, and (2) if there are significant relationships between the quantity of labile organic matter present in the sediments covered by the mat and the mat itself. We believe that these elements are preliminarily necessary to understand how a bottom-floating mat can last so long at very high densities, demonstrating considerable resistance to environmental adversity, and to develop better environmental management of these critical lagoon environments, since not solving the problem of macroalgal blooms and their persistence, will make it difficult to achieve environmental remediation. Furthermore, we included among the objectives of the study to know (3) the percentage content of sulfur in the algal thalli since, in this regard, little information is available in the literature for the genus Chaetomorpha, and C. Linum in particular, even though some studies have found the presence of sulfated polysaccharides.

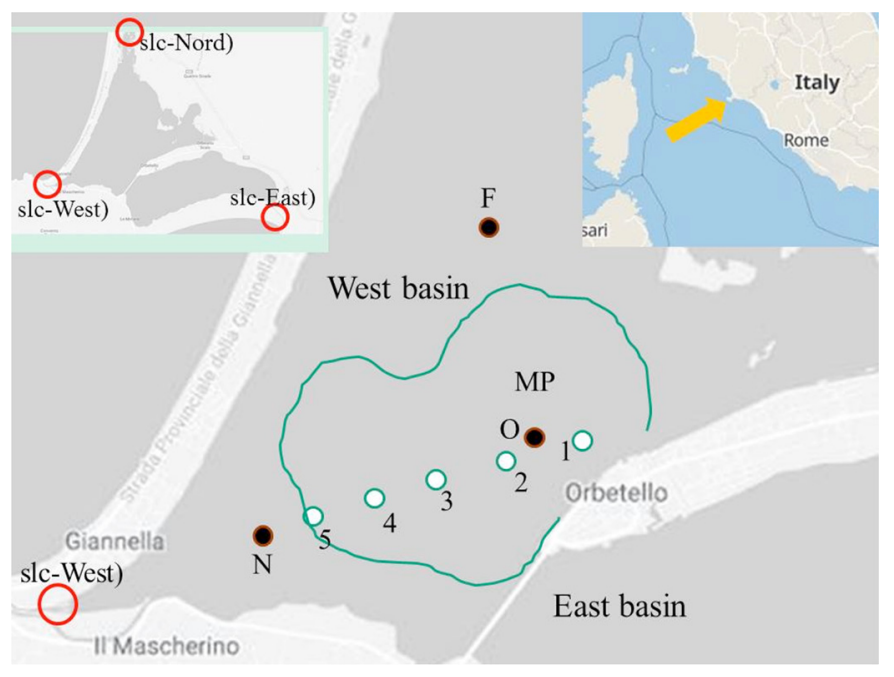

Fig. 1. Orbetello lagoon (Italy west coast). Area delineated in green, high density mat of $C$. linum; white points $(1,2,3,4,5)$, sampling stations for the analysis of algal tissue; black points (N, O, F), water sampling stations; MP, multiparameter probe on fixed location; red circles, sea-lagoon canals and marine mouths.

\section{Materials and methods}

\subsection{Study area}

The Orbetello lagoon is a shallow, eutrophic coastal water body of about $25.25 \mathrm{~km}^{2}$ in the southern Tuscan coast of Italy $\left(42^{\circ} 25^{\prime}-42^{\circ} 29^{\prime} \mathrm{N}, 11^{\circ} 10^{\prime}-11^{\circ} 17^{\prime} \mathrm{E}\right)$. This lagoon has two communicating basins known as "West" and "East", with an area of $15.25 \mathrm{~km}^{2}$ and $10.00 \mathrm{~km}^{2}$ respectively, and with a $1 \mathrm{~m}$ average depth (Fig. 1). Three artificial sea-lagoon canals, $0.5-3 \mathrm{~km}$ long and $10-15 \mathrm{~m}$ wide, two in the West (slc-Nord; slc-West) and one in the East basin (slc-East), connect the lagoon to the sea (Fig. 1). Because of the modest tidal excursions of the Tyrrhenian Sea and for the length and modest width of the three sea-lagoon canals, lagoon water turnover is poor and depends mainly on wind force and direction. Lagoon salinity ranges from 28 to 43 (practical salinity scale) changing with rainfall and evaporation.

The environment is eutrophic due to fish-farm wastewaters discharged in the East basin, intermittent streams containing agricultural run-off and civil effluent coming from the Albegna river, and historical input stored in the sediment (Lenzi et al., 2003). Due to high nutrient availability, morphology and lowwater-turnover, this lagoon is subject to severe macroalgal proliferation, which can cause dystrophic crises with consequential die-offs (Lenzi et al., 2011).

Macroalgal harvesting and sea-water pumping were the first management actions taken to counteract the eutrophication effects. Macroalgal harvesting took place for 6 months per year and removed 4000-6000 tonnes per year of wet algal mass. It was estimated that 6000 tonnes of macroalgae removed from the ecosystem involved the resuspension of over 15,000 tonnes of sediment (Lenzi et al., 2013b). From 2014, the main action to counter eutrophication has mainly been based only on direct resuspension of the sediment anoxic top layer (Lenzi et al., 2017). Sea-water pumping is still practiced 


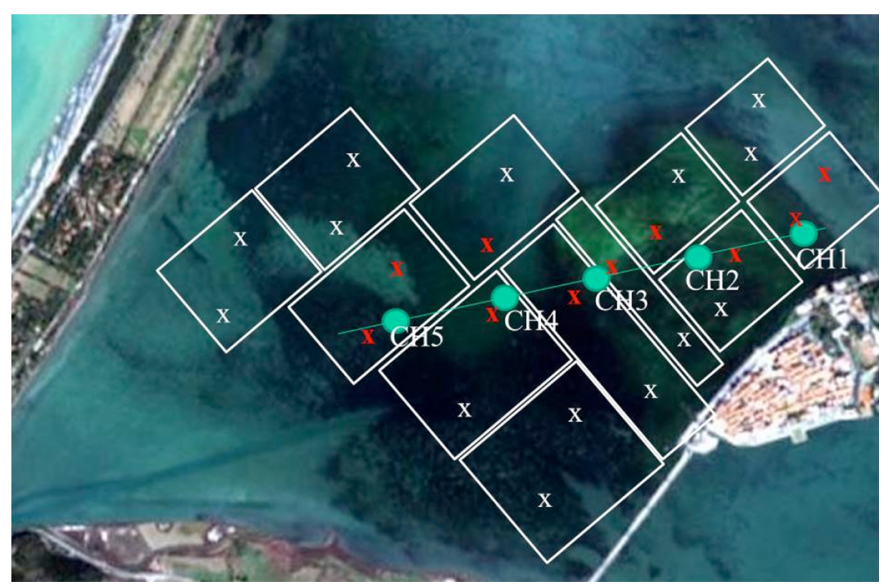

Fig. 2. Extension of the mat in January 2018 in the west basin of the Orbetello lagoon. Blank squares, areas of division of the mat for sampling of LOM (x) and biomass; green spheres, sampling stations for the tissue content of algae; $\mathrm{x}$ in red, LOM sampling stations close to those of the algal thalli, used for correlation analysis.

every year, between June and August, to promote water turnover, with the input from two western pumping stations placed at the mouth of the two western sea-lagoon canals, and with the output by the eastern sea-lagoon canal (Fig. 1).

This study was conducted on a high density mat of $C$. linum extending over 300 hectares located in the south-western area of the West basin (Figs. 1 and 2).

\subsection{Conceptual models of the high density macroalgal mat growth and decay}

Chaetomorpha linum (Müller) Kütz. is a thin, filamentous unbranched structured Chlorophyta widely distributed in bays, lagoons and estuaries all over the world. It is bottom-floating and can proliferate considerably to form dense and thick mats (Lavery et al., 1991; McGlathery et al., 1997; Menéndez et al., 2002; Sorce et al., 2017).

In the Orbetello lagoon, $C$. linum growth was estimated within about the first $20 \mathrm{~cm}$ of the mat, while the underlying part did not carry out photosynthesis (Sorce et al., 2017). When the macroalga cannot perform photosynthesis, it can be subjected to bacterial attacks (Krause-Jensen et al., 1996), to the point that the last decimeter of the mat thickness decays and produces organic mud on the bottom, enriching the sediment in carbon and nitrogen (Corzo et al., 2009) and, in turn, affecting the microbial community (García-Robledo et al., 2008). The anaerobic mineralization that occurs at the sediment-water interface releases inorganic nutrients toward the water column (McGlathery et al., 2001), such as ammonium $\left(\mathrm{NH}_{4}{ }^{+}\right.$) (Marty et al., 1990), carbon dioxide $\left(\mathrm{CO}_{2}\right)$ and orthophosphate $\left(\mathrm{PO}_{4}{ }^{3-}\right.$ ) (Peckol and Rivers, 1995a). Phosphorus release occurs mainly in the anoxic degradation of organic detritus (Peckol and Rivers, 1995b). Oxygen and $\mathrm{pH}$ decreases lead to the reduction of the $\mathrm{Fe}^{3+}$ which involves the breaking of the bond of $\mathrm{PO}_{4}{ }^{3-}$ with the ferric oxides-hydroxides (Holmer, 1999), and subsequently its release into the water column (Gao et al., 2013). This can support growth of the mat, but also liberates soluble and acid volatile sulfides $\left(\mathrm{H}_{2} \mathrm{~S}, \mathrm{HS}^{-}, \mathrm{S}^{2-}\right.$; AVS) by the sulfate-reduction bacterial activity, which can accelerate the under-layer mat decay (Nedergaard et al., 2002). In these dynamics, therefore, macroalgal mats can constitute both a sinking and a source of nutrients (Sfriso et al., 1987; Hanisak, 1993). The mat is thus self-sustaining in a continuum, and can increase or decrease in density in relation to the prevalence of the activity of its over-layer or that of the bacteria on the under-layer. Zou et al. (2020) emphasized a positive feedback between macroalgal blooms and benthic $P$ flux, and, due to the impacts of internal nutrient cycling (macroalgae and sediment), affirmed that lake (and lagoon, we say) ecosystems often showed vain recovery efforts precisely for this reason.

In the mat over-layer, where macroalgal growth is highest, $\mathrm{N}$ and $\mathrm{P}$ availability from upward diffusion of benthic flux could be low due to under-layer macroalgal uptake. In such a case, nutrients should be taken from the water column, causing a downward flux of nutrients from surface into the mat over-layer. Under these conditions, paradoxically, dissolved nutrients analyses provide very often an oligotrophic framework, and are not reliable to determine the actual trophic state of the basin and nutritional bioavailability (Peckol et al., 1994; McGlathery et al., 1997). In this regard, in a high density mat of C. linum, Lenzi et al. (2013a) observed dissolved nutrient stratifications with relatively higher values on the bottom of $\mathrm{N}-\mathrm{NH}_{4}$, dissolved organic nitrogen (DIN), and soluble reactive phosphorus (SRP), while DIN:SRP atomic ratio was decreasing downward. Moreover, they observed significant tissue nutrient stratification: a greater accumulation of $\mathrm{N}$ and $\mathrm{P}$ in the under-layer thalli than in over-layer.

\subsection{Water quality detemination}

Physico-chemistry values of the water column were obtained by a multiparameter probe (MP) installed on a fixed location placed in the western basin inside the $C$. linum mat (Fig. 1). The MP was immersed at $50 \mathrm{~cm}$ on $160 \mathrm{~cm}$ of the water column, about $10 \mathrm{~cm}$ from the surface of the mat, and sent the readings every $15 \mathrm{~min}$ by GSM frequencies. Variables measured were dissolved oxygen (DO, mg L ${ }^{-1}$ ), $\mathrm{pH}$ and temperature $\left(\mathrm{T},{ }^{\circ} \mathrm{C}\right)$. Salinity (s, practical salinity scale) was measured directly in situ during the monthly sampling trials by an ATAGO S/Mill refractometer.

For the water column dissolved nutrient, three sampling stations were positioned: one $(\mathrm{N})$ on the southwestern edge of the mat, towards the SW sea-mouth; the second (F) at the northern edge of the mat, towards the North sea-mouth; the third (O) near MP, in the heart of the higher density part of the mat. Water samples were collected monthly in March, June and October 2017, February, May, July and October 2018, and April 2019. Samples were refrigerated and quickly brought to the laboratory for analysis, where they were filtered at $0.40 \mu \mathrm{m}$. Nitrates $\left(\mathrm{N}^{-\mathrm{NO}_{3}}{ }^{-}\right)$, total dissolved nitrogen (TDN), soluble reactive phosphorus (SRP) and total dissolved phosphorus (TDP) were determined. The analyses were conducted according to APAT IRSA-CNR (2003). N-NO SRP molar ratio was them computed.

\subsection{Mat density estimates}

West basin $C$. linum mat examined (Fig. 1), characterized by high biomass $\left(>5 \mathrm{~kg} \mathrm{~m}^{-2}\right)$, has persisted in this area stably 
since 2008 (Lenzi et al., 2011, 2013a), even during severe dystrophic crises (Sorce et al., 2017), occupying a bottom surface-area between 450 and 350 hectares and moving between east and west by no more than $500-600 \mathrm{~m}$.

Trials to measure the $C$. linum biomass (b) were conducted in June and October 2017, February, May, July and October 2018 and April 2019. The mat had previously been divided into 12 areas (Fig. 2), marked with flags and georeferenced, within which 3 samples were collected along a diagonal transect of each area, by avoiding the few and not very large bare bottom holes. Therefore, 36 samples for the whole mat were weighed for each trial. Samples were collected inside a square metal frame of $3600 \mathrm{~cm}^{2}(60 \times 60 \mathrm{~cm})$, drained for $3 \mathrm{~min}$ and weighed directly on board with a portable electronic balance with sensitivity $\pm 0.5 \mathrm{~g}$. The values were then expressed in $\mathrm{kg}$ wet weight per square meter $\left(\mathrm{kg}_{\mathrm{Ww}} \mathrm{m}^{-2}\right)$, using conversion factors, according to equation (1):

$$
\mathrm{b}_{\mathrm{x}} \mathrm{kg}_{\mathrm{WW}} 3600 \mathrm{~cm}^{-2^{*}} 10^{-4^{*}} 2.778=\mathrm{b}_{\mathrm{y}} \mathrm{kg}_{\mathrm{WW}} \mathrm{m}^{-2}
$$

where $b_{x}$ is the in situ weighted value.

Mat standing crops were then calculated according to equation (2):

$$
\mathrm{SC}=\mathrm{b} * \mathrm{CT} * 10^{-3}
$$

where $b$ results from the average of all the estimated values $\left(b_{y}\right)$; CT is the total cover of the substrate by the algal mats estimated through Sentinel-2 satellite images, obtained from the Land-Viewer site (EOS DATA ANALYTICS, USGS/ NASA), and calculated through the Fiji-Image software (Schindelin et al., 2012); $10^{-3}$ is the conversion factor for $\mathrm{kg}$ into tonnes, as standing crop was expressed in tonnes wet weight $\left(\mathrm{T}_{\mathrm{WW}}\right)$.

\subsection{Sediment labile organic matter estimates}

Trials to measure the labile organic matter (LOM) in the top sediment of the substrate covered by the mat were conducted in November 2016, May, July, September and November 2017, April, July, September and November 2018, January, March and June 2019. In each trial, two sediment samples were collected from each of the 12 areas into which the mat was divided (Fig. 2), for a total of 24 samples.

After having displaced the algal layer, $3-4 \mathrm{~cm}$ sediment top-layer samples were collected with a $60 \mathrm{~mL}$ syringe, lowered from the boat and guided by an appropriate device (Lenzi and Renzi, 2011). The samples were frozen until analysis. All samples were wet sieved with fresh water $(1 \mathrm{~mm}$ mesh), dried at $75^{\circ} \mathrm{C}$ for $48 \mathrm{~h}$ and then weighed. Labile organic matter (LOM) was determined as loss of weight after combustion in a muffle furnace for $6 \mathrm{~h}$ at $250^{\circ} \mathrm{C}$ (Loh, 2005).

\subsection{CNPS content in Chaetomorpha linum}

The macronutrients $\mathrm{C}, \mathrm{N}, \mathrm{P}$ can constitute a limiting factor in the physiology and growth of aquatic vegetation. $\mathrm{C}$ can limit growth in important bloom conditions, through an intense hoarding of $\mathrm{CO}_{2}$, so many species have developed the strategy of using bicarbonates. $\mathrm{N}$ and $\mathrm{P}$ can constitute important limiting factors and cause stunting. On the contrary, they can abound in eutrophic conditions and produce high accumulations in algal thalli. In sulfate-rich marine environments, it is not known if $\mathrm{S}$ is a limiting factor. Conversely, in eutrophic environments subject to intense dystrophic phenomena, $\mathrm{S}$ could accumulate in the thalli as sulfides, as observed in seagrass (Holmer and Nielsen, 2007), and constitute a source for the production of hydrogen sulfide during the anaerobic decay of the plant mass. For this last reason, we also wanted to take this macronutrient into account, of which there is little information in the literature as an elementary component of this opportunistic macroalgae.

The sampling of the $C$. linum thalli was carried out in five stations $(\mathrm{CH} 1-\mathrm{CH} 5)$ arranged along a transect that proceeded from the edge of the mat close to the urban center, towards the marine mouth of SW (slc-West; Figs. 1 and 2). Eight sampling trials were conducted between 2017 and 2019 (March, June and October 2017, February, May, July and October 2018, and April 2019). At each station, two samples of thalli (1 kg each) at the surface of the mat (in the first $20 \mathrm{~cm}$ ), about $50 \mathrm{~m}$ apart from each other, were taken and immediately refrigerated. Subsequently, in the lab, the samples were quickly washed with fresh water to remove the salt and debris, dried with paper towels to remove the water in excess, and then dried with an air jet fan. The samples were carefully cleaned of concretions, animals and impurities, using silicone gloves to avoid contaminating the material, and the result obtained was dried at constant weight at $75^{\circ} \mathrm{C}$, and used for analytical determinations.

Total tissue $\mathrm{C}$ was determined with the Walkley-Black method (Soltner, 1988) and $\mathrm{N}$ with the Kjeldahl method (Egli, 2008). P and S were determined using an inductively coupled plasma - optical emission spectrometry instrument, ICP-OES Agilent 5110, U.S. (Boss and Fredeen, 2004). Using the percentages of the estimated macronutrients, the molar ratios $\mathrm{C}: \mathrm{P}, \mathrm{N}: \mathrm{P}, \mathrm{C}: \mathrm{N}$ and $\mathrm{C}: \mathrm{S}$ were subsequently calculated. We have introduced the atomic ratio $\mathrm{N}: \mathrm{S}$ to compare the dynamics of S with respect to the relationship that exists between the two elements in proteins (tissue proteins, nuclear proteins, hormones, enzymes, etc.), whereby $\mathrm{N}$ is present for $16 \%$ and $\mathrm{S}$ varies between $0.5 \%$ and $3.5 \%$, with an atomic ratio $\mathrm{N}: \mathrm{S}$ between 89 and 13 .

\subsection{Statistical analysis}

Data of macroalgal thalli macronutrient content $(C, N, P, S)$ were processed by one way ANOVA, respectively with month (8 levels) and station (5 levels) as fixed and orthogonal factors for each analysis, in order to detect significant differences among sampling trials and stations, respectively.

Cochran's $C$-test was used before each analysis to check for homogeneity of variance and data were $\ln (x)$ transformed when necessary (Underwood, 1997). The post-hoc Tukey's test was used to perform a posteriori multiple comparisons of means. Significant effects were considered for $p<0.05$.

Linear regressions analyses were performed to test the relationship between thalli macronutrient contents and LOM values obtained in the same stations or in very close pointstations (Fig. 2), at about the same time of the thalli sampling (LOM1), and at 2-3 months earlier than the thalli sampling (LOM2). The degree of correlation between each macronutrient and LOM was calculated and reported as squared correlation coefficient (determination coefficient, $r^{2}$ ). The relationship with macronutrients was also tested for 
macroalgal biomass $(b)$ following the same procedure. Significance of regressions was tested by the Fisher's exact test $(F)$.

\section{Results}

\subsection{Water quality}

The monthly ranges of the chemical-physical variables monitored during the period examined by the MP placed in the

Table 1. Physico-chemistry variables of the water column obtained by a multiparameter probe placed in the western basin inside the C. linum mat. DO, dissolved oxygen; $\mathrm{pH} ; \mathrm{T}$, temperature; s, salinity (practical salinity scale).

\begin{tabular}{lllll}
\hline & DO mg L & $\mathrm{pH}$ & $T^{\circ} \mathrm{C}$ & $\mathrm{s}$ \\
\hline March-17 & $4.5-12.0$ & $8.16-8.90$ & $11.4-17.7$ & 29 \\
June-17 & $0.0-11.4$ & $7.15-8.41$ & $24.9-31.6$ & 34 \\
Oct-17 & $4.0-17.5$ & $8.20-8.82$ & $16.2-22.9$ & 42 \\
Febr-18 & $5.6-9.2$ & $8.14-8.68$ & $7.7-12.5$ & 30 \\
May-18 & $0.0-20.0$ & $8.10-9.10$ & $17.4-27.0$ & 32 \\
July-18 & $0.0-10.5$ & $7.33-8.70$ & $23.8-31.1$ & 37 \\
Oct-18 & $3.0-12.7$ & $8.25-8.65$ & $19.0-22.9$ & 40 \\
Apr-19 & $3.3-9.2$ & $8.30-8.47$ & $12.9-20.2$ & 32 \\
\hline
\end{tabular}

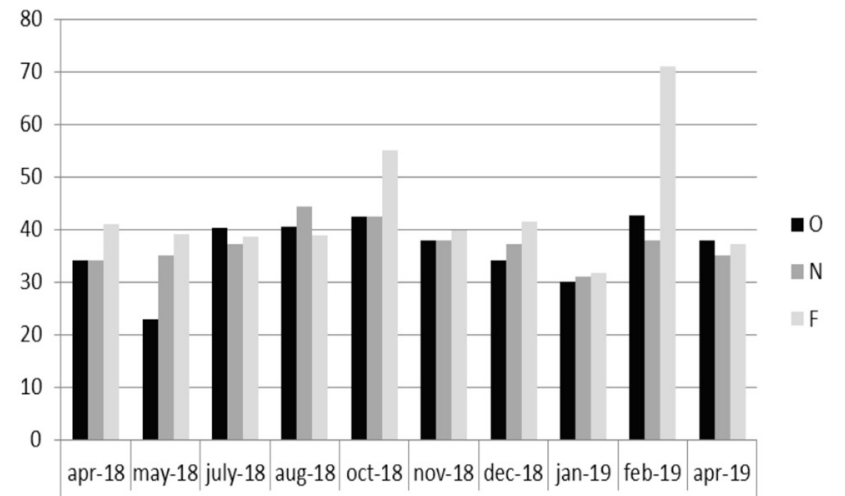

$\mathrm{N}-\mathrm{NO3}$

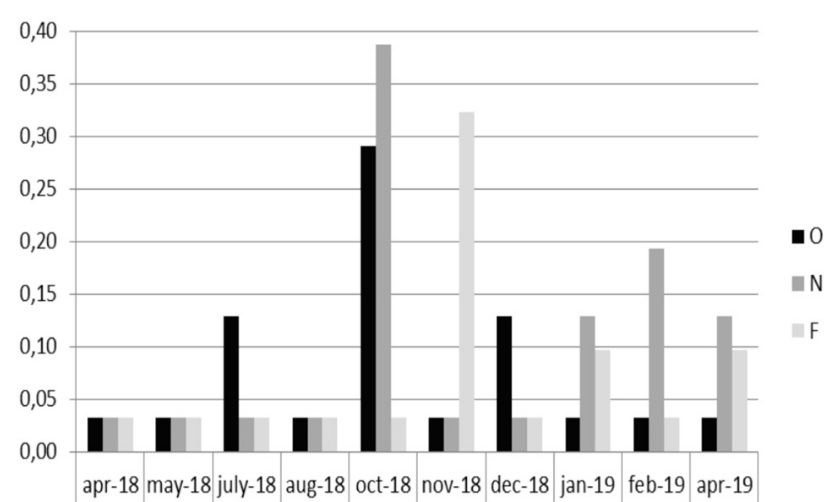

SRP center of the $C$. linum mat, are shown in Table 1. DO, $\mathrm{pH}$ and $\mathrm{T}$ showed wide variability within the same month. In the warmer months, DO values dropped to zero at night and in the early morning, while in the hours of intense illumination the values often increased in over-saturation. Temperature varied widely over the same month, even $10^{\circ} \mathrm{C}$, as a consequence of meteorological events, due to the low inertia of a laminar water column to atmospheric events. Salinity was more stable within the same month, varying between one month and another in relation to meteorological events and summer evaporation.

Dissolved nutrient concentration, estimated between April 2018 and April 2019 in the water column of the stations O (inside the mat) and $\mathrm{N}$ and $\mathrm{F}$ (at the western and north margins of the mat, respectively), are shown in Figure 3. Means $( \pm \mathrm{SD})$ of $\mathrm{N}-\mathrm{NO}_{3}, \mathrm{TDN}, \mathrm{SRP}$ and TDP for the entire period examined, for each station and for all records, are reported in Table 2. SRP values presented the widest variability, those of TDP were a little less variable. Nitrate values proved less variable overall and, above all, within each month, and highlighted the northern station as a probable major source, while TDN, although the variability of the data was relatively important, presented values greater within the mat.

Calculating the molar ratio $\mathrm{N}-\mathrm{NO}_{3}: \mathrm{SRP}$, omitting the components of ammonia and nitrous nitrogen, which have never been higher overall on average than $4 \mu \mathrm{M}$, high P-limitation values were obtained, with $835 \pm 423,782 \pm 479$,
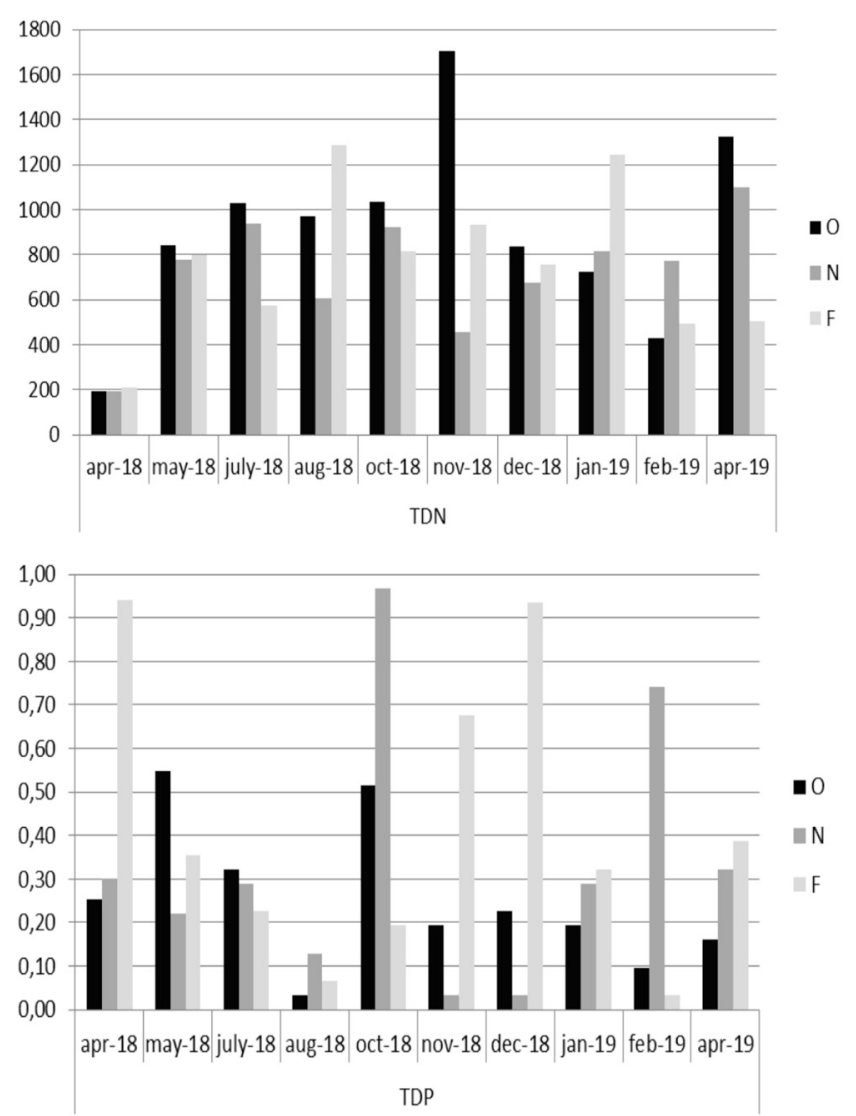

Fig. 3. Nitric nitrogen $\left(\mathrm{N}-\mathrm{NO}_{3}\right)$, total dissolved nitrogen (TDN), soluble reactive phosphorus (SRP) and total dissolve phosphorus (TDP) trends, in $\mu \mathrm{M}$, estimated between April 2018 and April 2019 at stations-O, central in C. linum mat, station-N, at the end of the SW boundary of the mat, and station-F, at the end North boundary of the mat, in the west basin of the Orbetello lagoon. 
Table 2. Dissolved nutrient in $\mu \mathrm{M}$ (mean $\pm \mathrm{SD}$ ) estimated in the sampling stations $\mathrm{O}, \mathrm{N}$ and $\mathrm{F}$, placed inside and on the edges of the $C$. linum mat. $\mathrm{N}-\mathrm{NO}_{3}$, nitric nitrogen; SRP, soluble reactive phosphorus; TDN, total dissolved nitrogen; TDP, total dissolved phosphorus. TM, total mean $( \pm \mathrm{SD})$ among all the station records.

\begin{tabular}{lllll}
\hline & $\mathrm{O}$ & $\mathrm{N}$ & $\mathrm{F}$ & $\mathrm{TM}$ \\
\hline $\mathrm{N}-\mathrm{NO}_{3}$ & $36.25 \pm 5.89$ & $37.17 \pm 3.72$ & $43.31 \pm 10.75$ & $38.91 \pm 8.03$ \\
$\mathrm{SRP}$ & $0.08 \pm 0.08$ & $0.10 \pm 0.11$ & $0.07 \pm 0.09$ & $0.08 \pm 0.09$ \\
$\mathrm{TDN}$ & $907.97 \pm 403.11$ & $726.42 \pm 247.69$ & $761.19 \pm 320.03$ & $798.53 \pm 339.04$ \\
$\mathrm{TDP}$ & $0.25 \pm 0.16$ & $0.33 \pm 0.28$ & $0.41 \pm 0.31$ & $0.33 \pm 0.27$ \\
\hline
\end{tabular}

Table 3. Means $( \pm \mathrm{SD})$ among the 36 biomass stations (b) of the entire C. linum mat, and related monthly standing crop (SC), estimated between June-17 and April-19.

\begin{tabular}{lll}
\hline & $\mathrm{b}, \mathrm{kg}_{\mathrm{ww}} / \mathrm{m}^{2}$ & $\mathrm{SC}$, tonnes ww \\
\hline June-17 & $11.80 \pm 7.68$ & 35837 \\
Oct-17 & $7.86 \pm 4.92$ & 26690 \\
Feb-18 & $8.85 \pm 4.67$ & 25850 \\
May-18 & $8.10 \pm 5.62$ & 28480 \\
July-18 & $7.05 \pm 5.54$ & 24787 \\
Oct-18 & $8.23 \pm 4.04$ & 28885 \\
Apr-19 & $7.82 \pm 5.115$ & 27348 \\
\hline
\end{tabular}

$1090 \pm 611$ for O, N, F, respectively, for a range between all the stations of $109-2199$.

\subsection{Mat density estimates}

The extension of $C$. linum mat between June 2017 and April 2019 fluctuated between 366 and 340 hectares (Fig. 2). The monthly means $( \pm \mathrm{SD})$ of biomass for the entire mat and the estimates of SC are shown in Table 3. Among all available records $(n=252)$, the mean was $9.07 \pm 5.40 \mathrm{~kg}_{\mathrm{Ww}} \mathrm{m}^{-2}$ and the median $8.55 \mathrm{~kg}_{\mathrm{WW}} \mathrm{m}^{-2}$. The mean mat density was highest in the first monthly estimate; subsequent estimates were lower by $25-40 \%$ compared to the initial month. The mat was almost surfacing in the part close to the city of Orbetello, and deepened going west, the water column height varying between 100 and $170 \mathrm{~cm}$.

\subsection{Sediment labile organic matter}

For the entire mat sediment area, the LOM mean of all records (T-LOM), estimated for the sediments immediately below the mat, was $9.99 \pm 3.79 \%$, the median $9.02 \%$, in a range of $4.27-25.48 \%$. Monthly LOM means $( \pm \mathrm{SD})$ for the entire mat sediment area (M-LOM) are shown in Table 4. On average, the highest organic load values in sediments below the mat occurred between July 2017 and September 2018.

\subsection{CNPS content and atomic ratios}

A total of 80 records were obtained for the 8 trials, for each macronutrient present in the $C$. linum thalli, from which $\mathrm{C}$ resulted on average $2205 \pm 1003 \mu \mathrm{mol} \%$ (median $2017 \mu \mathrm{mol} \%$ ),
Table 4. Means $( \pm \mathrm{SD})$ among all 24 sampling stations, of the percentage of labile organic matter per month (M-LOM) present in the sediments covered by the $C$. linum mat, between November-2016 and June-2019.

\begin{tabular}{ll}
\hline & M-LOM \\
\hline Nov-16 & $7.91 \pm 2.68$ \\
May-17 & $9.58 \pm 2.71$ \\
July-17 & $11.63 \pm 3.74$ \\
Sept-17 & $12.68 \pm 5.01$ \\
Nov-17 & $10.15 \pm 3.83$ \\
Apr-18 & $11.47 \pm 4.91$ \\
July-18 & $9.30 \pm 3.48$ \\
Sept-18 & $11.49 \pm 3.00$ \\
Nov-18 & $9.39 \pm 2.30$ \\
Jan-19 & $8.58 \pm 2.26$ \\
Mar-19 & $8.54 \pm 1.71$ \\
June-19 & $8.94 \pm 4.19$ \\
\hline
\end{tabular}

$\mathrm{N} \quad 102 \pm 49 \mu \mathrm{mol} \quad \% \quad($ median $102 \mu \mathrm{mol} \quad \%$ ), P $2.188 \pm$ $1.412 \mu \mathrm{mol} \%$ (median $1.745 \mu \mathrm{mol} \%$ ) and $\mathrm{S} 51.00 \pm 0.33$ $\mu \mathrm{mol} \%$ (median $52 \mu \mathrm{mol} \%$ ), with range of $1525-3804 \mu \mathrm{mol} \%$, 42.60-177.80 $\mu \mathrm{mol} \%, \quad 0.329-5.677 \mu \mathrm{mol} \%$, 36.56-72.43 $\mu \mathrm{mol} \%$, respectively.

In Table 5, means ( $\pm \mathrm{SD}$ ) and medians of each macronutrient between all the records of each trial (March 2017-April 2019) and among all the records of each station (CH1-CH5) are reported.

Results of one-way ANOVA analysis indicated that values of macroalgal thalli macronutrient content significantly varied with factor Month, with the exception of P (Tab. 6). However, high variability of the data for the $\mathrm{C}, \mathrm{P}$ and $\mathrm{S}$ values was highlighted by the non-homogeneity of the variances at the Cochran test. The post-hoc Tukey's test comparison showed significantly higher values of $\mathrm{N}$ content in March-17 compared to values observed in both June and October-17 $(p<0.01)$ while values of thalli collected in June-17 resulted significantly lower than those collected in July-18 $(p<0.05)$. Similarly, thalli macronutrient content did not vary significantly among the stations with the exception of $\mathrm{N}$, although high variability of data for this variable was highlighted by the Cochran's test (Tab. 6).

Linear regressions analysis showed no significant correlation between $\mathrm{P}, \mathrm{N}$ and $\mathrm{S}$ with LOM1 or LOM2; in the same way, $\mathrm{C}$ values were not significantly correlated with LOM2 
M. Lenzi et al.: Knowl. Manag. Aquat. Ecosyst. 2020, 421, 38

Table 5. Monthly means ( \pm SD) and medians of C, N, P, S percentages, using the records of all 5 stations, and means ( \pm SD) and medians of each of the stations using all the records available between March-17 and April-19.

\begin{tabular}{|c|c|c|c|c|c|c|c|c|}
\hline & \multicolumn{2}{|c|}{$\mathrm{C}$} & \multicolumn{2}{|c|}{$\mathrm{N}$} & \multicolumn{2}{|c|}{$\mathrm{P}$} & \multicolumn{2}{|c|}{ S } \\
\hline & Mean & Median & Mean & Median & Mean & Median & Mean & Median \\
\hline Mar-17 & $24.40 \pm 0.55$ & 24.40 & $2.03 \pm 0.75$ & 1.55 & $0.040 \pm 0.020$ & 0.039 & $1.79 \pm 0.15$ & 1.78 \\
\hline June-17 & $19.16 \pm 3.05$ & 18.90 & $0.99 \pm 0.29$ & 0.99 & $0.030 \pm 0.010$ & 0.036 & $1.02 \pm 0.12$ & 1.02 \\
\hline Oct-17 & $19.07 \pm 2.03$ & 19.15 & $1.05 \pm 0.50$ & 1.07 & $0.080 \pm 0.040$ & 0.082 & $1.97 \pm 0.17$ & 2.00 \\
\hline Feb-18 & $22.42 \pm 1.77$ & 23.15 & $1.71 \pm 0.72$ & 1.55 & $0.110 \pm 0.050$ & 0.114 & $1.58 \pm 0.14$ & 1.57 \\
\hline May-18 & $21.94 \pm 2.21$ & 21.65 & $1.52 \pm 0.48$ & 1.62 & $0.040 \pm 0.020$ & 0.047 & $1.63 \pm 0.32$ & 1.55 \\
\hline July-18 & $38.43 \pm 3.77$ & 36.88 & $1.53 \pm 0.41$ & 1.78 & $0.070 \pm 0.040$ & 0.081 & $1.65 \pm 0.07$ & 1.64 \\
\hline Oct-18 & $32.92 \pm 7.37$ & 30.78 & $1.29 \pm 0.29$ & 1.39 & $0.057 \pm 0.042$ & 0.046 & $1.72 \pm 0.13$ & 1.64 \\
\hline Apr-19 & $32.88 \pm 2.56$ & 32.65 & $1.42 \pm 0.40$ & 1.35 & $0.074 \pm 0.028$ & 0.077 & $1.89 \pm 0.18$ & 1.87 \\
\hline CH 1 & $28.02 \pm 10.41$ & 24.20 & $1.23 \pm 0.48$ & 1.32 & $0.070 \pm 0.038$ & 0.072 & $1.66 \pm 0.35$ & 1.74 \\
\hline $\mathrm{CH} 2$ & $25.59 \pm 8.21$ & 22.20 & $1.31 \pm 0.44$ & 1.45 & $0.074 \pm 0.041$ & 0.059 & $1.61 \pm 0.38$ & 1.64 \\
\hline CH 3 & $26.37 \pm 6.52$ & 25.10 & $1.39 \pm 0.41$ & 1.43 & $0.059 \pm 0.026$ & 0.052 & $1.62 \pm 0.26$ & 1.66 \\
\hline $\mathrm{CH} 4$ & $26.21 \pm 7.65$ & 23.50 & $1.41 \pm 0.47$ & 1.40 & $0.062 \pm 0.040$ & 0.046 & $1.62 \pm 0.30$ & 1.67 \\
\hline $\mathrm{CH} 5$ & $26.13 \pm 5.35$ & 24.40 & $1.83 \pm 0.83$ & 1.82 & $0.074 \pm 0.054$ & 0.056 & $1.67 \pm 0.33$ & 1.61 \\
\hline
\end{tabular}

Table 6. Results of one way ANOVA performed on macroalgal thalli macronutrient content for the Month and Station source of variability. Significant $P$ values are reported in bold type; ns, not significant.

\begin{tabular}{|c|c|c|c|c|c|c|c|c|c|}
\hline & \multirow[b]{2}{*}{ Source } & \multicolumn{4}{|c|}{ Month } & \multicolumn{4}{|c|}{ Stations } \\
\hline & & $\mathrm{df}$ & MS & $F$ & $P$ & $\mathrm{df}$ & MS & $F$ & $P$ \\
\hline \multirow[t]{3}{*}{$\mathbf{C}$} & RES & 7 & 516.30 & 35.86 & 0.0000 & 4 & 12.06 & 0.20 & 0.9394 \\
\hline & & 72 & 14.40 & & & 75 & 61.37 & & \\
\hline & TOT & 79 & & & & 79 & & & \\
\hline \multicolumn{2}{|c|}{ Cochran's test } & & \multicolumn{3}{|c|}{$\mathrm{C}=0.5243(P<0.01)$} & & \multicolumn{2}{|c|}{$\mathrm{C}=0.3557(\mathrm{~ns})$} & \\
\hline \multirow[t]{3}{*}{$\mathbf{N}$} & RES & 7 & 1.28 & 4.34 & 0.0005 & 4 & 1.13 & 3.31 & 0.0148 \\
\hline & & 72 & 0.29 & & & 75 & 0.34 & & \\
\hline & TOT & 79 & & & & 79 & & & \\
\hline \multicolumn{3}{|c|}{ Cochran's test } & \multicolumn{3}{|c|}{$\mathrm{C}=0.2628(\mathrm{~ns})$} & & \multicolumn{2}{|c|}{$\mathrm{C}=0.4830(P<0.01)$} & \\
\hline \multirow[t]{3}{*}{$\mathbf{P}$} & RES & 7 & 0.02 & 1.87 & 0.0865 & 4 & 0.1105 & 0.19 & 0.9413 \\
\hline & & 72 & 0.01 & & & 75 & 0.5722 & & \\
\hline & TOT & 79 & & & & 79 & & & \\
\hline \multicolumn{3}{|c|}{ Cochran's test } & \multicolumn{3}{|c|}{$\mathrm{C}=0.9035(P<0.01)$} & & \multicolumn{2}{|c|}{$\mathrm{C}=0.3612(\mathrm{~ns})$} & \\
\hline \multirow[t]{3}{*}{$\mathbf{S}$} & RES & 7 & 0.83 & 24.52 & 0.0000 & 4 & 0.0111 & 0.10 & 0.9818 \\
\hline & & 72 & 0.03 & & & 75 & 0.1097 & & \\
\hline & TOT & 79 & & & & 79 & & & \\
\hline \multicolumn{3}{|c|}{ Cochran's test } & \multicolumn{4}{|c|}{$\mathrm{C}=0.4169(P<0.01)$} & \multicolumn{2}{|c|}{$\mathrm{C}=0.2636(\mathrm{~ns})$} & \\
\hline
\end{tabular}

data-set, while significant correlation, albeit modest, was observed with LOM1 data-set (Tab. 7). An equally modest significant correlation between thalli macronutrient content and macroalgal biomass was observed only for nitrogen (Tab. 7).

$\mathrm{C}: \mathrm{P}, \mathrm{N}: \mathrm{P}, \mathrm{C}: \mathrm{N}, \mathrm{N}: \mathrm{S}$ atomic ratios are reported in Table 8 as mean $( \pm \mathrm{SD})$ and median between all the stations for each trial, and between all the trials for each station. Means $( \pm \mathrm{SD})$, medians and ranges between all records for the four atomic ratios are shown in Table 9.

\section{Discussion}

$\mathrm{DO}, \mathrm{pH}$ and $\mathrm{T}$ values (Tab. 1) highlighted extreme environmental conditions periodically arose in the mat area. In particular, as early as March, DO was depleted between
Table 7. Values of the squared correlation coefficient $\left(r^{2}\right)$ and Fisher's test $(F)$. Significant $F$ values were reported in bold.

\begin{tabular}{lll}
\hline & $r^{2}$ & $F$ \\
\hline C - LOM1 & 0.087 & $\mathbf{0 . 0 1 3 0}$ \\
N - LOM1 & 0.018 & 0.2693 \\
P - LOM1 & 0.010 & 0.4112 \\
S - LOM1 & 0.051 & 0.0591 \\
C - LOM2 & 0.013 & 0.3440 \\
N - LOM2 & 0.000 & 0.9526 \\
P - LOM2 & 0.012 & 0.3786 \\
S - LOM2 & 0.012 & 0.3615 \\
C - b & 0.038 & 0.1060 \\
N - b & 0.179 & $\mathbf{0 . 0 0 0 3}$ \\
P - b & 0.012 & 0.3767 \\
S - b & 0.034 & 0.1268 \\
\hline
\end{tabular}


Table 8. Monthly means $( \pm \mathrm{SD})$ and medians of the C:P, N:P, C:N, N:S atomic ratios, using the records of all 5 stations, and means ( \pm SD) and medians of each of the stations using all the records available between March-17 and April-19.

\begin{tabular}{|c|c|c|c|c|c|c|c|c|}
\hline & \multicolumn{2}{|c|}{$\mathrm{C}: \mathrm{P}$} & \multicolumn{2}{|c|}{$\mathrm{N}: \mathrm{P}$} & \multicolumn{2}{|c|}{$\mathrm{C}: \mathrm{N}$} & \multicolumn{2}{|c|}{$\mathrm{N}: \mathrm{S}$} \\
\hline & Mean & Median & Mean & Median & Mean & Median & Mean & Median \\
\hline March-17 & $2357 \pm 1346$ & 1613 & $146 \pm 55$ & 155 & $16 \pm 5$ & 19 & $2.7 \pm 1.2$ & 2.1 \\
\hline June-17 & $1691 \pm 921$ & 1298 & $65 \pm 11$ & 68 & $25 \pm 12$ & 21 & $2.2 \pm 0.6$ & 2.6 \\
\hline Oct-17 & $810 \pm 419$ & 525 & $36 \pm 9$ & 34 & $22 \pm 10$ & 21 & $1.2 \pm 0.6$ & 1.1 \\
\hline Febr-18 & $510 \pm 150$ & 487 & $36 \pm 12$ & 35 & $15 \pm 5$ & 17 & $2.5 \pm 1.0$ & 2.2 \\
\hline May-18 & $1699 \pm 1349$ & 1157 & $103 \pm 100$ & 85 & $19 \pm 7$ & 17 & $2.2 \pm 0.8$ & 2.3 \\
\hline July-18 & $1798 \pm 1417$ & 1295 & $59 \pm 23$ & 53 & $29 \pm 15$ & 26 & $2.4 \pm 0.7$ & 2.4 \\
\hline Oct-18 & $1818 \pm 843$ & 1845 & $62 \pm 32$ & 58 & $31 \pm 10$ & 29 & $1.8 \pm 0.4$ & 1.8 \\
\hline Apr-19 & $1466 \pm 885$ & 1204 & $56 \pm 42$ & 36 & $29 \pm 9$ & 27 & $1.7 \pm 0.4$ & 1.8 \\
\hline CH1 & $1417 \pm 1033$ & 1254 & $59 \pm 51$ & 46 & $27 \pm 12$ & 22 & $1.8 \pm 0.7$ & 1.9 \\
\hline $\mathrm{CH} 2$ & $1159 \pm 669$ & 900 & $49 \pm 31$ & 38 & $24 \pm 8$ & 23 & $2.0 \pm 0.7$ & 2.1 \\
\hline $\mathrm{CH} 3$ & $1516 \pm 1207$ & 1301 & $60 \pm 25$ & 67 & $25 \pm 14$ & 20 & $2.0 \pm 0.7$ & 2.0 \\
\hline $\mathrm{CH} 4$ & $1537 \pm 991$ & 1295 & $71 \pm 49$ & 61 & $24 \pm 9$ & 24 & $2.0 \pm 0.6$ & 2.0 \\
\hline $\mathrm{CH} 5$ & $1909 \pm 1091$ & 1603 & $97 \pm 93$ & 66 & $22 \pm 12$ & 16 & $2.5 \pm 1.1$ & 2.3 \\
\hline
\end{tabular}

Table 9. Means $( \pm \mathrm{SD})$ and of the C:P, N:P, C:N, N:S atomic ratios, using all available records.

\begin{tabular}{lllll}
\hline & $\mathrm{C}: \mathrm{P}$ & $\mathrm{N}: \mathrm{P}$ & $\mathrm{C}: \mathrm{N}$ & $\mathrm{N}: \mathrm{S}$ \\
\hline Mean \pm SD & $1498 \pm 1124$ & $67 \pm 55$ & $24 \pm 11$ & $2.1 \pm 0.8$ \\
Median & 1189 & 50 & 22 & 2.0 \\
Range & $5623-327$ & $395-18$ & $69-9$ & $0.7-4.7$ \\
\hline
\end{tabular}

the night and the early hours of the morning, due to intense respiratory activity, while in the hours of insolation the values went up to supersaturate the water column. With the first increase in temperature, then, the values dropped to zero, at night, even for several hours, to recover in the daytime phase. Similarly, $\mathrm{pH}$ increased strongly, due to alkalinization produced by photosynthesis, but it fell well below the more stable marine values, when respiration dominated, due to $\mathrm{CO}_{2}$ increase. Acidification of the mat substrate and part of the water column could be a stressor, although Young and Gobler (2016) observed, for mats of Gracilaria sp. and Ulva sp., an increase in growth due to $\mathrm{CO}_{2}$ partial pressure rise. $\mathrm{CO}_{2}$ increase induced a shift from the use of bicarbonate to that of $\mathrm{CO}_{2}$ itself as a source of $\mathrm{C}$ (bicarbonate mainly used consequently to the diurnal limitation of $\mathrm{CO}_{2}$ to high density of the mat). This increase in growth occurred despite the relative acidification of the environmental conditions of the mat.

In the sampling stations for dissolved nutrients $\mathrm{O}$, and $\mathrm{F}$, on a few occasions, SRP values were higher than the analytical detection limit, and this happened just a little more in the station N. Zou et al. (2020) observed a positive feedback between macroalgal blooms and benthic P flux, and this was certainly true also in our case; but highlighting this in the field depends on many factors, not least the thickness of the mat. In fact, our results, for a mat between 50 and $100 \mathrm{~cm}$ thick, confirmed the difficulty of SRP to go up along the water column and fully affect the over-layer mat, as already noted by Lenzi et al. (2013a), despite the over-layer mat being the only part of the mat that can grow. The lesser variability of TDP was probably due to a greater quantity of organic component (dissolved organic phosphorus), as already observed in this lagoon (Lenzi et al., 2015). Nitrates, on the other hand, were quite stable, maintaining more or less the same order of magnitude of values in the three stations, with slightly higher values in station $F$ (Tab. 2). This station is $3 \mathrm{~km}$ from the lagoon-mouth of the North sea-lagoon canal (slc-North), which at the opposite end, in turn, flows near the sea-mouth of Albegna river. The significant annual contribution of nitrogen by the river, ascertained by DICEA (2018), might reach the northern margins of the mat (Fig. 1).

$\mathrm{N}-\mathrm{NO}_{3}: \mathrm{SRP}$ molar ratio expressed an extreme P-limitation in the first $20-30 \mathrm{~cm}$ of the water column. If we consider that the optimal Redfield N:P ratio for phytoplankton is 16 and macroalgae have values around 30 (Atkinson and Smith, 1982), the water column did not bring nutrients in a physiologically balanced ratio for $C$. linum. Hence, $\mathrm{P}$ availability might have constituted a limiting factor for achieving the physiologically necessary tissue ratio. However, C. linum, although it is not a nitrophilous species and prefers to accumulate $P$, is rarely considered to be nutrient-limited even for the latter, unless subject to prolonged nutrient scarcity (Lavery et al., 1991). This may mean the times in which the orthophosphates managed to reach the surface of the water column were sufficient to allow adequate storage of $\mathrm{P}$ in the over-layer mat thalli by a very efficient uptake.

The biomass showed consistently high values (Tab. 3), which, in some areas, as a consequence of the wind pressure on the mat, exceeded $30 \mathrm{~kg}_{\mathrm{ww}} \mathrm{m}^{-2}$. Biomass also varied seasonally with winter minimums and spring maximums, to which must be added the effects of anthropic interventions that aimed to mitigate the problem (Lenzi et al., 2017), and more or less extensive summer dystrophic events. Consequently, LOM values were consistently very high (Tab. 4), with peaks greater than 20\%. High mat biomass and high LOM established constant anaerobic condition in the sediments which in the spring-summer period led to the release of AVS up to $30-40 \mathrm{~cm}$ from the bottom (detected in the field by injecting a few drops 
of $\mathrm{FeCl}_{2}$ solution at different depths). The high density created a permanent extreme condition, which did not lead to the collapse of the mat, but allowed its self-regeneration and probably freed it from competition with other species.

$\mathrm{C}$ content showed a large fluctuation with periods of probable limitation, between June and October 2017, which could have led consequence of physiological stress, and with values of relative abundance, between July 2018 and April 2019. We have no data to establish the reasons for these fluctuations, however we must take into account that, in addition to the high densities, between 2014 and 2016 the mat was subjected to intense disturbance through the resuspension of the top layer sediment by boats (Lenzi et al., 2017), and to a heavy dystrophic event (Sorce et al., 2017), which may have contributed to the mat decline. Starting from 2017, the mat was restored, as soon as the anthropogenic pressure was reduced, showing a high resilience.

C. linum thalli, even in a context of wide variability both between stations and between months, showed a tendency towards P-limitation, the tissue molar ratio $\mathrm{N}: \mathrm{P}$ very often being greater than 30 (Atkinson and Smith, 1983; Wheeler and Bjornsater, 1992), with an average of $67 \pm 57$ and a median of 49. These results agree with those of a previous study conducted in another $C$. linum high density mat of the same lagoon (Lenzi et al., 2013a), in which tissue P-limitation was found, with N:P mean values of about 170, and more storage of $\mathrm{N}$ and $\mathrm{P}$ in the mat under-layer than in the over-layer. This indicates that the under-layer was a filter of the nutrients released from the sediment. That study and the present study suggest that the over-layer mat adapted to long periods of limitation alternating with periods of $\mathrm{P}$ availability, during which the storage that the thalli managed to carry out was probably sufficient for growth and maintenance.

Sulfur content was relatively high, much greater than that required for formation of proteins containing cysteine and methionine. The $\mathrm{N}: \mathrm{S}$ atomic ratio was about 2, compared to an expected range of $89-13$ for proteins only. Sulfur, in fact, is also present in sulfolipids of the cell membranes, as a constituent of vitamins, regulatory compounds, and in a number of sulfur-metabolites, such as dimethylsulfonionpropionate (van Bergeijk, 2000; Gambaro et al., 2007). The latter is a tertiary sulfonic compound present in the cells of various species of macroalgae and microalgae, functioning as an osmoregulator, cryoprotectant and antibacterial. Moreover, some Chlorophyta can synthesize sulfated polysaccharides, such as ulvans in the cell wall of Ulvaceae, which are known to be inducers of plant immunity (Jaulneau et al., 2010; Li et al., 2018). Having strong antioxidant activity, they can neutralise reactive oxygen species (ROS) and reactive nitrogen species (RNS) (Qi and Sun, 2015). According to Bischof et al. (2006), $C$. linum is highly tolerant to UV and PAR radiation. If we consider that the over-mat can reach the surface of the water column, it can increase production of antioxidant molecules and super-oxide dismutase activity as a physiological acclimation strategy to persistent and high light exposure. In addition, Freile-Pelegrín et al. (2020) extracted watersoluble sulfated polysaccharides with gelling capacity and antioxidant activity from Chaetomorpha gracilis. Pierre et al. (2011) obtained a water-soluble extract from Chaetomorpha aerea, consisting of a sulfated (6.3\%) galactan and dextran sulfate or fucoidan polysaccharides that showed selective antibacterial activities. A similar result was obtained for C. linum by Rosaline et al. (2017), and Venkata Rao and Sri Ramana (1991) detected the presence of sulfated arabinogalactans in Chaetomorpha anteninna.

Our results showed that the quantity of sulfur is more stable compared to the other three macronutrients, as evidenced by the N:S atomic ratio (Tab. 8). Moreover $C$. linum never manifested S-limitation conditions. In fact, since the sulfur demands of algae are met mainly by the sulfate, sulfur is unlikely to be a growth limiting factor for algae in marine and lagoon environments (Hawkesford, 2008).

Using the records of all 5 stations, monthly means and medians of C, N, P, S were found to vary from each other, more than the means and medians of each station varied from each other, using all the records available between March-17 and April-19. This means greater seasonal variability, rather than between one area and another on the mat (Tab. 5). Moreover, the high data dispersion did not allow to establish significant variations with due reliability among both stations and months for $\mathrm{C}, \mathrm{P}, \mathrm{S}$; only $\mathrm{N}$ showed significant differences for a few months (Tab. 6). This last result could be a seasonal effect, when the months that differed from each other were June and October 2017 from March 2017, where this last month had higher $\mathrm{N}$ values, and the months of the intermediate seasons the lower values, probably due to intense mat growth; while the significant difference between June 2017 and July 2018, with the latter month having highest values due to macroalgal decay, was due to local and meteorological factors.

No correlations were found between the macronutrients neither with LOM nor with biomass. The modest correlations observed, $\mathrm{C}-\mathrm{LOM} 1$ and $\mathrm{N}-\mathrm{b}$, have a $r^{2}$ decidedly too low to take them into account (Tab. 7). Since labile organic matter is a source of nutrients and the algal mass creates sedimentary anoxia capable of releasing orthophosphates, it is conceivable that the over-layer mat captured the nutrients during the brief period in which they were available in the upper layer of the water column, storing and using them quickly in view of their scarcity, so that the cycles of biomass, organic matter in the sediments, and the macronutrients contained in the thalli, were disconnected and apparently random.

$\mathrm{C}: \mathrm{N}$ and, above all, $\mathrm{N}: \mathrm{S}$ showed greater data homogeneity, compared to C:P and N:P (Tabs. 8 and 9). This depended on the percentage values of $\mathrm{N}$ and $\mathrm{S}$ in the thalli, the latter in particular resulted fairly stable in the various samples monthly and over the entire period examined, and on the wide variability of $\mathrm{P}$.

\section{Conclusions}

The responses to the goals we set, i.e. any changes in the macronutrients $\mathrm{C}, \mathrm{N}, \mathrm{P}, \mathrm{S}$ content in a high density mat of $C$. linum, and any significant relationships between the quantity of LOM present in the sediments covered by the mat, and the density of the mat itself, are summarized in the following points: the seasons and, above all, the extreme summer environmental conditions can affect the content of the macronutrients, but significant changes were not observed between the different sampling points along the mat in each of the trials; significant relationships between mat density and LOM were not highlighted. As for the content in S of the thalli, 
as a third objective, it was relatively high. The variability of the data, however, does not reveal a synchronous behavior of the mat.

Over a long period, we observed that when a mat of C. linum "takes root" in an area, it remains for a long time, unless there are important environmental events. We hypothesize that the accumulations of bottom-floating macroalgal masses in a given area, can be random, often due to the wind, therefore normally this occurs in relatively low-energy areas where what is pushed and accumulated no longer moves; but then the high density of the mat and the accumulation of high quantities of LOM in the sediment impose peculiar environmental conditions, in a sort of process of colonization of the territory. And it is precisely in these conditions, chaotic, variable and tendentially extreme, that $C$. linum finds advantage because it re-assimilates nutrients of its own degradation, collects atmospheric carbon in addition to that deriving from its degradation. This prevents $\mathrm{C}$-limitation that could occur at very high densities, and seems to help it tolerate bacterial aggressions. This tolerance could be due to the presence of antibacterial sulfur-metabolites, which could explain, at least in part, the considerable resilience to environmental adversity of $C$. linum high density mat; the quantity of $\mathrm{S}$ in the thalli allows us to consider this possibility as an important element to be investigated in further research.

Acknowledgments. The authors thank Orbetello Pesca Lagunare Company for logistical support during the research in field, and Laurence Mason M.Sc. (University of Nottingham, UK) for the English revision of the text.

\section{References}

Amanieu M, Baleux B, Guelorget O, Michel P. 1975. Étude biologique et hydrologique d'une crise dystrophique (Malaïgue) dans l'étang du Prévost à Palavas (Hérault). Vie Milieu 25: 175-204.

APAT, IRSA-CNR. 2003. Metodi Analitici per le Acque. ISBN 88-448-0083-7, 1: 1153.

Atkinson MJ, Smith SV. 1983. C:N:P ratios of benthic marine plants. Limnol Oceanogr 28: 568-574.

Bischof K, Rautenberger R, Brey L, Pérez-Lloréns JL. 2006. Physiological acclimation to gradients of solar irradiance within mats of the filamentous green macroalga Chaetomorpha linum from southern Spain. Mar Biol Progr Ser 306: 165-175.

Bombelli V, Lenzi M. 1996. Italy-the Orbetello lagoon and the Tuscan coast. In: Schhramm, W., Nienhuis, P.N. (Eds.), Marine Benthic vegetation. Ecological Studies, vol. 123. Berlin Heidelberg: Springer-Verlag, pp. 331-337.

Boss CB, Fredeen KJ. 2004. Concepts, Instrumentation and Techniques in Inductively Coupled Plasma Optical. Emission Spectrometry. 3rd Edition. 120pp.

Cohen RA, Fong P. 2004. Physiological responses of a bloomforming green macroalga to short-term change ib salinity, nutrient, and light help explain its ecological success. Estuaries 27: 209-216.

Corzo A, Van Bergeijk SA, García-Robledo E. 2009. Effects of green macroalgal blooms on intertidal sediments: net metabolism and carbon and nitrogen contents. Mar Ecol Progr Ser 380: 81-93.
DICEA. 2018. Research activity for the mitigation of eutrophic processes in the Orbetello Lagoon: Study on the estimation of the nutrient balance and on the numerical model of the hydrodynamic circulation. Final technical-scientific report. Department of Civil and Environmental Engineering (DICEA), University of Florence. Tuscany region. $264 \mathrm{pp}$.

Duck RW, Figueiredo da Silva J. 2012. Coastal lagoons and their evolution: a hydromorphological perspective. Estuar Coast Shelf Sci 110: 2-14.

Egli H. 2008. Kjeldahl Guide. Flawil Switzerland: Büchi Labortechnik AG.

Freile-Pelegrín Y, Chávez-Quintal C, Caamal-Fuentes E, VázquezDelfin E, Madera-Santana T, Robledo D. 2020. Valorization of the filamentous seaweed Chaetomorpha gracilis (Cladophoraceae, Chlorophyta) from an IMTA system. J Appl Phycol https://doi.org/ 10.1007/s10811-020-02066-8.

Gambaro A, Cescon P, Turetta C, Piazza R, Moret I. 2007. Studio dei composti organici solforati volatili di origine marina e loro relazione con i cambiamenti climatici. In 2 - Clima e cambiamenti climatici le attività di ricerca del CNR, a cura di B. Carli, G. Cavarretta, M. Colacino, S. Fuzzi, Published pp. https://issuu.com/ cnr-dta. CNR Dipartimento Scienze del Sistema Terra e Tecnologie per l'Ambiente, 81-84 pp.

Gao L, Zhang L, Hou J, Wei Q, Fu F. 2013. Decomposition of macroalgal blooms influences phosphorus release from the sediments and implications for coastal restoration in Swan Lake, Shandong, China. Ecol Eng 60: 19-28.

García-Robledo E, Corzo A, Garcia de Lomas J, Van Bergeijk SA. 2008. Biogeochemical effects of macroalgae decomposition on intertidal microbenthos: a microcosm experiment. Mar Ecol Progr Ser 356: 139-151.

Hanisak MD. 1993. Nitrogen release from decomposing macroalgaes: species and temperature effects. J Appl Phycol 5: $175-181$

Hargrave BT, Holmer M, Newcombe CP. 2008. Towards a classification of organic enrichment in marine sediments based on biogeochemical indicators. Mar Pollut Bull 56: 810-824.

Hauxwell J, Valiela I. 2004. Effects of nutrient loading on shallow seagrass dominated coastal systems: patterns and processes. In: Nielsen, S.L., Banta, G.T., Pedersen, M.F. (Eds.), Estuarine Nutrient Cycling: The Influence of Primary Producers. Dordrecht, The Netherlands: Kluwer Academic Publishers, pp. 59-92.

Hawkesford MJ. 2008. Uptake, distribution and subcellular transport of sulfate. In: Hell R, Dahl C, Knaff DB, Leustek T (Eds.), Supfur metabolism in phototrophic organism. Dordrecht: Springer, pp 15-30.

Holmer M. 1999. The effect of oxygen depletion on anaerobic organic matter degradation in marine sediments. Estuar Coast Shelf Sci 48: 383-390.

Holmer M, Duarte CM, Boschker HTS, Barrón C. 2004. Carbon cycling and bacterial carbon sources in pristine and impacted Mediterranean seagrass sediments. Aquat Microb Ecol 36: 227-237.

Holmer M, Nielsen RM. 2007. Effects of filamentous algal mats on sulfide invasion in eelgrass (Zostera marina). $J$ Exp Mar Biol Ecol 353: $245-252$.

Jaulneau V, Lafitte C, Jacquet C, Fournier S, Salamagne S, Briand X, Esquerŕe-Tugay M-T., Dumas B. 2010. Ulvan, a Sulfated Polysaccharide from Green Algae, Activates Plant Immunity through the Jasmonic Acid Signaling Pathway. $J$ Biomed Biotechnol 2010: Article ID 525291, 11 pages. 
Krause-Jensen D, Mc Glathery K, Rysgaard S, Christensen PB. 1996. Production within dense mats of the filamentous macroalga Chaetomorpha linum in relation to light and nutrient avalaibility. Mar Ecol Progr Ser 134: 207-216.

Lavery PS, Lukatelich RJ, McComb AJ. 1991. Changes in the biomass and species composition of macroalgae in a eutrophic estuary. Estuar Coast Shelf Sci 33: 1-22.

Lenzi M. 2019. Hunters of sulfur-blooms. Eutrophic non-tidal lagoon environments and dystrophic mechanics. $116 \mathrm{pp}$. Ed. Pandion, Roma. http://pandion-edizioni.blogspot.it and www.pandion.it.

Lenzi M, Finoia MG, Gennaro P, Mercatali I, Persia E, Solari J, Porrello S. 2013b. Assessment of resuspended matter and redistribution of macronutrient elements produced by boat disturbance in a eutrophic lagoon. J Environ Manag 123: 8-13.

Lenzi M, Gennaro P, Mercatali I, Persia E, Solari D, Porrello S. 2013a. Physico-chemical and nutrient variable stratifications in the water 4 column and in macroalgal thalli as a result of high biomass mats 5 in a non-tidal shallow-water lagoon. Mar Pollut Bull 75: 98-104.

Lenzi M, Leporatti Persiano M, Gennaro P, Rubegni F. 2017. Artificial top layer sediment resuspension to counteract Chaetomorpha linum (Muller) Kutz. blooms in a eutrophic lagoon. Three years full-scale experience. J Aquacult Mar Biol 5: 00114.

Lenzi M, Palmieri R, Porrello S. 2003. Restoration of the eutrophic Orbetello lagoon (Tyrrhenian Sea, Italy): water quality management. Mar Pollut Bull 46: 1540-1548.

Lenzi M, Renzi M. 2011. Effects of artificial disturbance on quantity and biochemical composition of organic matter in sediments of a coastal lagoon. Knowl Manag Aquat Ecosyst 402: 08 .

Lenzi M, Renzi M, Nesti U, Gennaro P, Persia E, Porrello S. 2011. Vegetation cyclic shift in eutrophic lagoon. Assessment of dystrophic risk indices based on standing crop evaluation. Estuar Coast Shelf Sci doi:10.1016/j.ecss.2011.10.006.

Lenzi M, Salvaterra G, Gennaro P, Mercatali I, Persia M, Porrello S, Sorce C. 2015. A new approach to macroalgal bloom control in eutrophic, shallow water, coastal areas. J Environ Manag 150: 456-465.

Li Q, Luo J, Wang C, Tai W, Wang H, Zhang X, Liu K, Jia Y, Lyv X, Wang L, He H. 2018. Ulvan extracted from green seaweeds as new natural additives in diets for laying hens. J Appl Phycol 30: 2017-2027.

Liu D, Keesing JK, Xing Q, Shi P. 2009. World's largest macroalgal bloom caused by expansion of seaweed aquaculture in China. Mar Pollut Bull 58: 888-895.

Loh PS. 2005. An assessment of the contribution of terrestrial organic matter to total organic matter in sediments in Scottish sea lochs, Ph. D. thesis, UHI Millenium Institute, $350 \mathrm{pp}$.

Marty D, Esnault G, Caumette P, Ranaivoson-Rambeloarisoa E, Bertrand JC. 1990. Denitrification, sulfato-reduction et methanogenese dans les sediments superficiels d'un étang saumatre Méditerranéen. Oceanolog Acta 13: 199-210.

McGlathery KJ, Anderson IC, Tyler AC. 2001. Magnitude and variability of benthic and pelagic metabolism in temperate coastal lagoon. Mar Ecol Progr Ser 216: 1-15.

McGlathery KJ, Krause-Jensen D, Rysgaard S, Christensen PB. 1997. Patterns of ammonium uptake within dense mats of the filamentous macroalgae Chaetomorpha linum. Aquat Bot 59: 99-115.

Menéndez M, Herrera J, Comín FA. 2002. Effect of nitrogen and phosphorus supply on growth, chlorophyll content and tissue composition of the macroalga Chaetomorpha linum
(O.F. Müll.) Kütz. in a Mediterranean coastal lagoon. Sci Mar 66: $355-364$

Morand P, Briand X. 1996. Excessive growth of macroalgae: a symptom of environmental disturbance. Bot Mar 39: 491-516

Nedergaard RI, Risgaard-Petersen N, Finster K. 2002. The importance of sulfate reduction associated with Ulva lactuca thalli during decomposition: a mesocosm experiment. J Exp Mar Biol Ecol 275: 15-29.

Peckol P, Demeo-Anderson B, Rivers J, Valiela I, Maldonado M, Weiner J, Yates J. 1994. Growth, nutrient uptake capacities and tissue costituents of the macroalgae Gracilaria tikvahiae and Cladophora vagabunda, related to site-specific nitrogen loading rates. Mar Biol 121: 175-185.

Peckol P, Rivers JS. 1995a. Physiological responses of the opportunistic macroalgae Cladophora vagabunda (L.) van den Hoek and Gracilariopsis tikvahiae (McLachlan) to environmental disturbances associated with eutrophication. J Exp Mar Biol Ecol 190: 1-16.

Peckol P, Rivers JS. 1995b. Competitive interactions between the opportunistic macroalgae Cladophora vagabunda (Chlorophyta) and Gracilariopsis tikvahiae (Rodophyta) under eutrophic conditions. J Phycol 31: 229-232.

Pierre G, Sopena V, Juin C, Mastouri A, Graber M, Maugard T. 2011. Antibacterial activity of a sulfated galactan extracted from the marine alga Chaetomorpha aerea Against Staphylococcus aureus. Biotechnol Bioprocess Eng 16: 937-945.

Qi HM, Sun YL. 2015. Antioxidant activity of high sulfate content derivative of ulvan in hyperlipidemic rats. Int J Biol Macromol 76: 326-329.

Raffaelli DG, Raven JA, Poole LJ. 1998. Ecological impact of green macroalgal blooms. Oceanogr Mar Biol 36: 97-125.

Rosaline XD, Sakthivelkumar S, Chitra S, Janarthanan S. 2017. Antibacterial activity of the seaweeds Chaetomorpha linum and Padina gymnospora on human bacterial pathogens. J Environ Biotechnol Res 6: 43-52.

Schindelin J, Arganda-Carreras I, Frise E et al. 2012. Fiji: an opensource platform for biological-image analysis. Nat Methods 9: 676-682.

Sfriso A, Marcomini A, Pavoni B. 1987. Relationships between macroalgal biomass and nutrient concentrations in a hypertrophic area of the Venice lagoon. Mar Environ Resour 22: 297-312.

Smetacek V, Zingone A. 2013. Green and golden seaweed tides on the rise. Nature 504: 84-88.

Soltner D. 1988. Le bases de la production vegetale. Tome 1: Le sol. 16 editione. Collection Sciences et Tecniques Agricoles. Angers: Sainte Gemmes Sur Loire.

Sorce C, Persiano Leporatti M, Lenzi M. 2017. Growth and physiological features of Chaetomorpha linum (Müller) Kütz. in high density mats. Mar. Pollut Bull http://dx.doi.org/10.1016/j. marpolbul.2017.10.071.

Underwood AJ. 1997. Experiments in ecology. Their logical design and interpretation using analysis of variance. Cambridge, UK: Cambridge University Press, pp. 410-411.

van Bergeijk SA. 2000. Production of dimethylsulfonionpropionate and dimethylsulfide in intertidal sediment ecosystems. Thesis University of Amsterdam. ISBN: 90-5776-054-1.

Venkata Rao E, Sri Ramana K. 1991. Structural studies of a polysaccharide isolated from the green seaweed Chaetomorpha anteninna. Carbohydr Res 217: 163-170. 
Viaroli P, Bartoli M, Bondavalli C, Christian RR, Giordani G, Naldi M. 1996. Macrophyte communities and their impact on benthic fluxes of oxygen, sulphides, and nutrients in shallow eutrophic environments. Hydrobiologia 239: 105-119.

Wheeler PA, Bjornsater BR. 1992. Seasonal fluctuations in tissue nitrogen, phosphorus and $\mathrm{N}: \mathrm{P}$ for five macroalgal species common to the Pacific Northwest coast. J Phycol 28: 1-6.
Young CS, Gobler CJ. 2016. Ocean acidification accelerates the growth of two bloom-forming macroalgae. PLOS ONE 11: e0155152.

Zou R, Wu Z, Zhao L, Elser JJ, Yu Y, Chen Y, Liu Y. 2020. Seasonal algal blooms support sediment release of phosphorus via positive feedback in a eutrophic lake: Insights from a nutrient flux tracking modeling. Ecol Model 416.

Cite this article as: Lenzi M, Leporatti-Persiano M, Gennaro P. 2020. C, N, P, S content of the Chlorophyta Chaetomorpha linum (Müller)

Kützing in a vast high density mat of a Mediterranean non-tidal lagoon. Knowl. Manag. Aquat. Ecosyst., 421, 38. 